\title{
Het zesde zintuig
}

Citation for published version (APA):

Kingma, H. (2001). Het zesde zintuig: een ontdekkingsreis. Universiteit Maastricht. https://doi.org/10.26481/spe.20010202hk

Document status and date:

Published: 02/02/2001

DOI:

10.26481/spe.20010202hk

Document Version:

Publisher's PDF, also known as Version of record

\section{Please check the document version of this publication:}

- A submitted manuscript is the version of the article upon submission and before peer-review. There can be important differences between the submitted version and the official published version of record.

People interested in the research are advised to contact the author for the final version of the publication, or visit the DOI to the publisher's website.

- The final author version and the galley proof are versions of the publication after peer review.

- The final published version features the final layout of the paper including the volume, issue and page numbers.

Link to publication

\footnotetext{
General rights rights.

- You may freely distribute the URL identifying the publication in the public portal. please follow below link for the End User Agreement:

www.umlib.nl/taverne-license

Take down policy

If you believe that this document breaches copyright please contact us at:

repository@maastrichtuniversity.nl

providing details and we will investigate your claim.
}

Copyright and moral rights for the publications made accessible in the public portal are retained by the authors and/or other copyright owners and it is a condition of accessing publications that users recognise and abide by the legal requirements associated with these

- Users may download and print one copy of any publication from the public portal for the purpose of private study or research.

- You may not further distribute the material or use it for any profit-making activity or commercial gain

If the publication is distributed under the terms of Article $25 \mathrm{fa}$ of the Dutch Copyright Act, indicated by the "Taverne" license above, 
HET ZESDE ZINTUIG:

EEN ONTDEKKINGSREIS 
(1) Kingma, Mastricht 2001

ISBN 9052783012

Universitaite Pers Matastricht

Vormgeving en druk: Datawyse bv Maastricht 


\section{HET ZESDE ZINTUIG: EEN ONTDEKKINGSREIS}

Rede uitgesproken bij de aanvaarding van het ambt van hoogleraar in de Klinische Vestibulologie aan de Universiteit Maastricht op vrijdag 2 februari 2001 door

\section{Dr. H. Kingma}

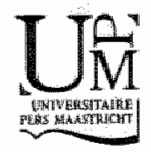





\section{MIJNHEER DE RECTOR MAGNIFICUS, DAMES EN HEREN,}

De meeste leerboeken willen ons doen geloven dat we maar vijf zintuigen hebben. Zintuigen voor zien, ruiken, proeven, voelen en horen. Maar, zijn er echt maar vijf zintuigen?

Metafysici en parapsychologen hebben al vele jaren geleden het bestaan van een zesde zintuig gepostuleerd. Onder dit zesde zintuig verstaan ze een zintuig waarmee we bijzondere dingen kunnen waarnemen waarvoor onze vijf aardse zintuigen ongevoelig zijn. Zo kan zonder hulpmiddelen gecommuniceerd worden met levenden op afstand en met overledenen, ook kunnen aardstralen gedetecteerd worden enz. enz. Paranormaal begaafden, zoals wichelroedelopers schijnen een goed ontwikkeld zesde zintuig te hebben. Gedegen onderzoek door een groep eminente wetenschappers in opdracht van de Koninklijke Academie van Werenschappen in de vijfriger jaren, alsmede wetenschappelijk onderzoek in de daarop volgende halve eeuw heeft nog geen afdoend bewijs voor her bestaan van dit zintuig kunnen opleveren. Maar dat er meer is onder hemel en aarde dan we nu kunnen begrijpen, leidt voor mij geen twijfel.

Een suggestie voor een andere kandidaat om als zesde zintuig te worden vermeld, kreeg ik na een zoekactie op het wetenschappelijk vaak verguisde internet: het orgaan van Jacobson, ook wel het vomero-nasale orgaan genoemd. Dit orgaan zou diverse lichaamsfuncties, alsmede stemming en gedrag kunnen beinvloeden. Het onderzoek naar deze fenomenen gaat terug tor in de jaren zestig, waar David Berliner ontdekte clat sommige reukloze stoffen, feromonen, die uir de menselijke huid geêxuraheerd werden, interessante effecten hadden op mensen: sommige mensen veranderden onder inademing van deze stoffen van stemming, anderen veranderden van gedrag, introverte mensen werden extroverter, actiever en communicatilever. Men postuleerde vervolgens dat het voor deze stoffen gevoelige 
zintuig niets anders zou zijn dan het in de neus gelegen $1 \mathrm{~cm}$ lange vomero-nasale orgaan, ofwel het orgaan van Jacobson. Het bestaan van dit orgaan werd in 1702 voor het eerst in de literatuur gemeld door de Nederlandse chirurg Frederik Ruys. Het is een apart chemoreceptief orgaan dat voorkomt in de meeste zoogdieren en reptielen en dat niet dient woor de waarneming van geuren.

Mike Meredith uit Florida toonde aan dat het vomero-nasale orgaan bij hamsters een belangrijke rol speelt bij paargedrag: zonder dit orgaan paren hamsters zonder sex-ervaring, niet of veel minder. Het is bekend dar de hypothalamus in de hersenen een belangrijke rol speelt bij sociaal en seksueel gedrag. Juist vanuit het vomero-nasale orgaan lopen zenuwbanen indirect naar de hypothalamus, waardoor een substraat ontstaat voor de invloed van feromonen op gedrag. Feromonen bevinden zich ook in ons menselijk zweet en lijken net als de seksgeurstoffen bij hamsters een functie te hebben bij de communicatie over onze lichaamsgesteldheid. Als voorbeeld kan het vrouwenslaapzaaleffect dienen. Bij vrouwen die dicht opeen leven zou na verloop van tijd de menstruatie synchroon gaan lopen. Martha McClintock van de universiteit van Chicago heeft recent in Nature het onderzoek beschreven waarin dit slaapzaaleffect, alsmede het bestaan van menselijke feromonen inderdaad werd aangetoond. Uiterst kleine hoeveelheden stoffen lijken dus rechtstreeks op de hyporhalamus en op stemming en gedrag in te werken. We kunnen een feromoon niet ruiken, niet zien en niet voelen, maar het kan de hersenfunctie wel beïnvloeden zonder dat we ons dat bewust zijn. De vraag is, of het effect van feromonen op mensen wel echt sterk is en, of de watarneming van feromonen ook bij mensen daadwerkelijk met het orgaan van Jacobsen plaatsvindr. Een interessant zintuig dus.

Maar ...... de beste kandidaat om als zesde zintuig genoemd te worden is het evenwichtsorgaan dat tot nu toe in de meeste leerboeken waarschijnlijk vanwege de relatief complexe fysische wer- 
keing maar beperkt behandeld wordt en ondergebracht wordt bij "het voelen" of de propriocepsis. Het evenwichtsorgan is onder meer erg belangrijk vanuir het perspectief van de patiënt. Wie heeft er zich nier ooit afgevraagd wat erger zou zijn: blind of doof? Ik verander die vraag in: blind, doof of constant duizelig? $\mathrm{Om} U$ de ernst van het probleem te schetsen, geef ik het volgende voorbeeld. Bij patiènten met zeer ernstige duizeligheid en misselijkheid op basis van een stoornis van het evenwichtsorgaan kunnen we tegenwoordig het evenwichtsorgaan chemisch of operatief uitschakelen, watrdoor de patiënt weliswaar niet meer duizelig is, maar wel het risico loopt doof te worden. Op de vraag of men dit risico wil lopen, is het antwoord meestal: of ik doof word interesseert me niet dokter, als ik maar van die duizeligheid en misselijkheid af ben. Met die duizeligheid is het geen leven meer. Misschien kunt $U$ zich voorstellen hoe het zou zijn als $U$ op de meest ongewenste momenten spontaan zeeziek zou worden, zonder dat er een schip in de buurt is.

Er wordt heel veel fundamenteel onderzoek naar het evenwichtsorgaan verricht vooral in relatie tot bewegingsziekte, oriëntatieproblemen van piloten in gevechtsvliegtuigen en ruimtevaart. De problemen die ontstaan door het ontbreken van de zwaartekracht in de ruimtevaart zijn groot: ruimteziekte is op dit moment misschien wel de grootste hindernis bij het verder exploreren van de ruimte. Er moet een oplossing voor bedacht worden want de mens is een ontdekkingsreiziger die vanzelfsprekend de mogelijkheid wil hebben in de ruimte te reizen en ergens anders dan op aarde wil kunnen leven. Op dit moment vindt op een aantal plaatsen in de wereld onderzoek plaats naar her effect van kunstmatig opgewelkte "zwaartekracht" op de evenwichtsfunctie om vere ruimtereizen mogelijk te maken.

Ik ben dus van mening dat het evenwichtsorgaan het meer dan waard is apart vermeld te worden net als de andere 5 hoofdzintuigen, en misschien zelfs wel als we toch onbescheiden worden, als 
het eerste of tweede zintuig. Na het reukorgaan is het evenwichtsorgaan immers ontogenetisch en fylogenetisch het oudste zintuig. Dat wil zeggen dat we deze zintuigen al bij zeer primitieve levensvormen aantreffen en dat ze in de embryonale ontwikkeling eerder aangelegd worden dan de ogen en het gehoor. Wat is nu toch eigenlijk dat evenwichtsorgaan en waar dient het precies voor?

Hoewell het evenwiches- en gehoororgaan bij de embryonale ontwikkeling allebei uit her zogenaamde gehoorblaasje ontstaan zijn, lijkr her feit dat ze allebei in het binnenoor gelegen zijn meer op toeval dan op noodzaak te wijzen. Toch is dit voor de $\mathrm{KNO}$-arts een gelukkige omstandigheid: hij mag het evenwichtsorgaan tot zijn werkgebied rekenen, ook al was de passie wan $\mathrm{KNO}$-artsen voor patiënten met evenwichtsstoornissen tot vóór het houden van deze rede zo ver ik weet nog beperkt.

De anatomen uit de $17 \mathrm{e}$ en $18 \mathrm{e}$ eeuw namen aan dat het gehele binnenoor, inclusief her evenwichtsorgaan voor het horen diende. De speciale oriëntatie van de verschillende onderdelen werd verklaard in relatie tot het kunnen lokaliseren van geluidsbronnen. Marie Jean Pierre Flourens was in 1824 de eerste die bij de duif aantoonde dat verwijdering van delen van het evenwichtsorgaan, of doorsnijden van de evenwichtszenuw het gehoor niet beïnvloedt, maar well leidt tot abnormale hoofdstanden en hoofdbewegingen. Daarmee was het evenwichtsorgaan ontdekt, wat ik nu maar het zesde zintuig zal noemen.

Heeft het evenwichtsorgaan misschien weinig met het gehoor te maken, des te meer lijkt her qua funcrie op het zijlijnsysteem in de vis. Dir zillijnsysteem, in bijwoorbeeld de haai, bestaat uit kleine openingen in de huid waardoor het zeewater in- en uitstroomt door een stelsel van buisjes. In de buisjes zitten fijne trilhaarcellen die de vloeistofbewegingen kunnen detecteren. De haai kan zo de kleinste vloeistofstromingen detecteren die optreden als hij zelf zwemt, of als andere dieren komen aanzwemmen. Bij de mens is het evenwichts- 
orgaan een gesloten compartiment, gevuld met wloeistof. De vloeistof komt dus alleen nog in beweging bij hoofdbewegingen. Het menselijk evenwichtsorgaan kan daardoor de hersenen precies informeren over de bewegingen van ons hoofd in de ruimte.

De evenwichtsorganen vormen een onderdeel van ons evenwichtsstelsel dat drie functies heeft: ruimtelijke orièntatie, beeldstabilisatie en houdingsregulatie. Om deze functie optimaal te kunner vervullen maakt het evenwichtsstelsel gebruik van elke mogelijke zintuiglijke input en van leerprocessen. Naast de evenwichtsorganen, zorgen ook het visuele systeem, de propriocepsis en het gehoor yoor voldoende informatie naar de hersenen on te kumnen weten hoe we staan en bewegen in de ruimte. Het evenwichtsorgaan is het meest belangrijke zintuig in ons evenwichtsstelsel en wel om drie redenen. Op de eerste plaats detecteren de evenwichtsorganen onze eigen bewegingen veel sneller dan onze ogen, waardoor we onder meer ook sneller kunnen reageren bij een dreigende val. Op de tweede plaats meten de evenwichtsorganen onze hoofdbewegingen in de ruimte in absolute zin, onafhankelijk van de bewegingen van de omgeving. Het visuele systeem meet alleen relatieve bewegingen: her kijkt alleen hoe wij ten opzichte van de zichtbare omgeving staan of bewegen. Op de derde plaats meet het evenwichtsorgaan onze absolute oriëntatie ten opzichte van de zwaartekracht: het vertelt ons wat boven en onder is, zodat we weten in welke richting we zullen vallen, zelfs in het donker.

In het navolgende zal ik aan de hand van een beschrijving van de drie functies van het evenwichtsstelsel aangeven hoe we in de kliniek trachten de functie van onze evenwichtsorganen te meten en welke bijdrage onze Maastrichtse kliniek door wetenschappelijk onderzoek daaraan geleverd heeft. 
Ruimtellijke orièntatie is moeilijk, zelfs onder normale dagelijkse omstandigheden. Stel dat $U$ in een trein zit die stil staat op het perron en ieder moment kan vertrekken. Naast $U$ staat ook een trein. Als we door het raam naar de trein naast ons kijken, en die trein wertrekt, hebben we waak ten onrechte de illusie alsof we zelf vertrelkken. Een fractie van een seconde later weten we dat onze rrein niet vertrokken is: we missen de stimulatie van andere zintuigen die deze interpretatic van zelfbeweging zouden moeten bevestigen. Immers, de evenwichtsorganen detecteren geen versnellingen, we horen geen motorgeluiden, we voelen geen vibraties van de motoren of de treinbeweging, we voelen geen druk van de rugzitring op onze rug. De illusie van zelfbeweging is dus zuiver visueel en aangeleerd. Van kinds af aan hebben we geleerd dat als we zelf bewegen we altijd de hele ongeving ten opzichte van onszelf zien bewegen. Bij bewegingen van objecten om ons heen beweegt altijd een object op een stilstaande achtergrond, waardoor we weten dat we niet zelf bewegen. Her bewegende beeld van de vertrekkende trein vult ons hele netvlies en geeft dus de illusie van een bewegende omgeving en daarmee het gevoel alsof we zelf bewegen. Onze ruimtelijke oriëntatie wordt sterk gedomineerd door de visuele input omdat onze ervaring geleerd heeft dat we meestal her beste op onze visuele waarneming kunnen vertrouwen. De sterke invloed van het visuele systeem is echter ook ten dele aangeboren. In Toronto is de vloer van een restaurant gedeeltelijk in glas uitgevoerd en biedt een volledig doorzicht op de 300 meter lager gelegen straten. Ondanks de wetenschap dat er niets kan gebeuren, kunnen maar weinig mensen hun angst overwinnen om op deze glazen vloer te gaan staan. Deze angst is ook aanwezig bij baby's en lijkt dus te zijn aangeboren (Wisual cliff fenomeen).

Uit het bovenstaande voorbeeld met de trein kunnen we concluderen dat ruimtelijke oriëntatie moeilijk is. Om de juiste conclusie re trekken hebben we informatie van zoveel mogelijk zintuigen 
nodig. Tijdens ons leven leren we multisensorische inputpatronen interpreteren en koppelen aan bepaalde bewegingsomstandigheden (staan, lopen, fietsen, autorijden, varen enz.). We slaan deze pa-tronen als "efference copies" in ons geheugen op, zodat we bepaalde bewegingspatronen snel kunnen herkennen en adequaat kunnen handelen.

De uiteindelijke waarneming van onze ruimtelijke oriëntatie in de ruimte en de duizeligheid bij bewegingsziekte en stoornissen van het evenwichesstelsel ontstaat waarschijnlijk in de hersenschors. Echter, recent onderzoek lijkt erop te wijzen dat er geen primair vestibulaire cortex bestaat, vergelijkbaar met de primaire visuele of auditieve cortex. We kunnen dit begrijpen vanuit het feit dat bij natuurlijke stimulatie van de evenwichtsorganen, meestal ook andere zintuigen geactiveerd worden. De labyrint informatie dient vooral voor ondersteuning van andere zintuiglijke functies, of is alleen relevant in combinatie met andere zintuiglijke informatie. Dit maakt een unimodale vestibulaire cortex waarschijnlijk overbodig. In overeenstemming hiermee, blijken de tor op heden geidentificeerde corticale neuronen die vestibulaire input ontvangen, steeds ook op somato-sensorische of opto-kinerische stimulatie te responderen. Gebieden in de cortex die een sterke vestibulaire input krijgen zijn onder meer de pariëto-insulaire "vestibulaire" cortex en area 7 van de inferieure pariëtale cortex. Het laatste is een gebied met multi-sensorische inpur voor ruimtelijke oriëntatie en visuo-motor controle.

De bij stimulatie of stoornissen van het evenwichtsorgaan optredende misselijkheid en braken, het transpireren, de werandering van harrslagfrequentic en ademhaling hebben een anatomisch substraat in de convergentic van de autonome en vestibulaire banen in de vestibulaire kernen en her archi-cerebellum. Afdalende banen uit de vesribulaire kernen projecteren op gebieden belangrijk voor medullaire cardiovasculaire en respiratoire controle en op gebieden belang- 
rijk voor het ontstaan van bewegingsziekre mer misselijkheid en brakeri. Opsuiggende banen projecteren op gebieden belangrijk voor affecrieve en emotionele responsies in de hypothalamus, amygdala en neo-cortex. De invloed van het vestibulair systeem op hartslag en ademhaling komt mogelijk doordat de regelprocessen inzake bloedcirculatie en ademhaling afhangen van de door het evenwichtsorgaan gedetecteerde stand van het lichaam ten opzichte van de zwaartekracht. Het ontstaan van misselijkheid en braken bij desorientatie heeft mogelijk primait een waarschuwende functie, die er toe noet leiden dat men gevaarlijke omstandigheden waarbij ruimtelijke desoriëntatie optreedt, voortaan mijdt.

Het is op zijn minst merkwaardig dat in vrijwel geen enkel ziekenhuis het ruimtelijke oriëntatievermogen van patiënten met stoornissen van het evenwichtsorgaan onderzocht wordt, terwijl dit wel uitgebreid in research laboratoria onderwerp van studie is. In thet verleden ontwikkelde Wim Bles bijwoorbeeld de zogenaamde kantelkamer, onder meer een meetinstrument om te testen in hoeverre patiënten zich bij het staan meer op proprioceptieve en vestibulaire dan op visuele informatie oriënteren. Een eenvoudige minder gevoelige variant hierop is de subjectieve visuele verticaal, waarbij de patiënt, staand in een volledig verduisterde ruimte, gevraagd wordt aan te geven wanneer een lichtbalk zo goed mogelijk verticaal staat. In Parijs onderzoekt Allain Berthoz onder meer de invloed van functiestoornissen van het evenwichtsorgaan op het vermogen om bij het lopen, afstand en richting juist in te schatten. In Maastricht ontwikkelde Susan Balter van onze onderzoeksgroep een test, de subjectieve proprioceptieve horizontaal, die meet in hoeverre mensen turnen voelen of de ondergrond waarop ze staan schuin staat of niet, kortom wat hun oriëntatie ten opzichte van hun steunvlak is. Met dit onderzoek naar ruimtelijk orièntatievermogen gekoppeld aan het staan, denken we een methode gevonden te hebben om bij 
patuënten met valneigingen uit te kunnen sluiten dat een stoornis van her evenwichtsorgaan oorzaak is van de valneiging.

Naast ruimtelijke orièntatie is beeldstabilisatie een belangrijke functie van het evenwichtsstelsel. Als we onze ogen niet zouden kunnen bewegen, zou bij iedere hoofdbeweging het beeld op ons nervlies voortdurend bewegen. Het visuele systeem is alleen in stat relatief stilstaande beelden met hoeksnelheden kleiner dan drie graden per seconde in de hersenen in detail te analyseren. Daarom is beeldstabilisatie bij hoofdbeweging noodzakelijk om tijdens hoofdbewegingen nog scherp te kunnen zien. Het visuele systeem is te traag om het beeld tijdig te stabiliseren. Tijdens snellere hoofdbewegingen wordt de beeldstabilisatie voornamelijk geregeld middels het snelle vestibulaire systeem door middel van de vestibulo-oculaire reflex. Hierbij detecteren de evenwichtsorganen de hoofdversnellingen en wordt in de hersenen de precieze hoofdsnelheid berekend. Op grond van deze berekening sturen de hersenen de oogspieren aan, met het gevolg dat de ogen met dezelfde snelheid als de hoofdsnelheid, maar in tegenovergestelde richting an de hoofdbeweging, bewegen. Hierdoor staat het beeld van de omgeving wrijwel stil op her netvlies, zodat het visuele systeem het beeld optimaal kan verwerken. Onderzoek naar beeldstabilisatie, of wel naar de vestibulo-oculaire reflex, vormt nog steeds de hoeksteen van het klinisch evenwichtsonderzoek.

Bij de standaard meting van de vestibulo-oculaire reflex worden alleen horizontale oogbewegingen en derhalve ook alleen de functie van de horizontale kanalen gekwantificeerd. Oogbewegingen wotden geregistreerd met behulp wan electro-oculografie dat vanwege de frequent woorkomende artefacten vaak moeilijk te interpreteren is. Patrick Huygen had om de electronystagmografie beter te kunnen kwantificeren op innovatieve wijze statistische technieken aangewend om nystagmus automatisch met de computer te herkennen. 
Hierdoor kwam een gederailleerdere analyse van responsies wan de horizontale kanalen binnen ons bereik.

Bij het gebruik van de electronystagmografie en de calorisatie bestonden een aantal problemen. De experimenten van Oosterveld en Scherer in gewichtsloosheid, en Wit, gewoon op de grond in Groningen maar uiterst elegant, maakten duidelijk dar de convectietheorie van Barany ter verklaring van de calorische reactie zijn beperkingen kende: de hoeksteen van het meten van de horizontale vestibullo-oculaire reflex, de calorisatie, leek te wankelen. De calorisatic is voor het evenwichtsonderzoek een belangrijke test omdat ze tot voor kort de enige algemeen geaccepteerde test was die de zijde, links of rechts, van een vestibulair functieverlies kon meten. Colebatch en Halmagyi ontwikkelden een alternatief: de vestibular evoked myogenic potential, een hoofdstabilisatie reflex die ipsilateraal ontstaat bij stimulatie van de sacculus. Een ander alternatief om verschillen in functie van het rechter en linker evenwichtssysteem te meten, is de al in 1820 door Purkinje beschreven galvanische stimulatie. Hierbij zorgt een klein elektrisch stroompje voor stimulatie van waarschijnlijk de evenwichtszenuw hetgeen leidt tot lichaamsbewegingen en oogbewegingen. Eerst Jaap van Twisk, en nu Susan Balter hebben in de Mastrichtse kliniek de handschoen opgenomen om met de compurertechnologie van nu, deze oude techniek tot een bruikbaar klinisch diagnostisch middel te ontwikkelen.

In de kliniek wordt beeldstabilisatie in het absolute donker gemeren om beïnvloeding door visuele stimuli te vermijden; hierdoor ontstaat echter de niet-fysiologische conditie waarbij men reflexen meet om beelden te stabiliseren terwijl er niets te zien is gevolg is dat de responsies sterk beinvloed worden door de alertheid en instructie van de patiënt en dat de slechte reproduceerbaarheid nauwelijks toelaat veranderingen van de evenwichtsfunctie of het effect van therapieen betrouwbaar te kwantificeren. In onze onderzoeksgroep ontwikkelde Hans Konijnenberg technieken om de ves- 
tibulo-aculaire reflex, fysiologischer, dus in het licht te kunnen meten (visueel-vestibulaire interactie) met echter een voor de kliniek vooralsnog te beperkte sensitiviteit. Een ander probleem bij het meten van de vestibulo-oculaire reflex is dat de beeldstabilisatie meestal gemeten wordt met langzame stimuli (calorisch onderzoek en draaistoeltesten), dus in een frequentiegebied waar het visuele systeem een grotere bijdrage levert aan de beeldstabilisatie dan het vestibulair systeem. Meten van de vestibulo-oculaire reflex bij hoge frequenties stuitte op problemen bij het adequaat overbrengen van snelle bewegingen op het hoofd en maakte het gebruik van patiëntonvriendelijke oogmetingstechnieken noodzakelijk (scleral-coiltechnieken). In Nederland was het vooral de groep van Collewijn in Rotterdam die deze problemen deels wist te omzeilen en meer inzicht in de hoogfrequente vestibulo-oculaire reflex verschafte. Anja Meulenbroeks van onze onderzoeksgroep paste de ideeën van Collewijn toe in de kliniek en kwam samen met hen en Aw en Halmagyi uit Sydney tot de conclusie dat hoogfrequent stimulatie gebruikmakend van snelle passieve snelheidsimpulsen functieverlies van de evenwichtsorganen kan detecteren dat tot op heden niet met andere technieken kon.

De andere onderdelen van het evenwichtsorgaan, het posterieure en anterieure kanaal, de utriculus en sacculus bleven bij de functiemetingen grotendeels buiten beschouwing. Pas in de afgelopen jaren is hierin verandering gekomen, waarbij in Nederland ten aanzien van de statolietenfunctie vooral de onderzoekers van TNO-Soesterberg, Bles, Bos, de Graaf en Wertheim, belangrijke bijdragen leverden. Bij stimulatie van de verticale kanalen en utriculus en sacculus ontstaan oogbewegingen in drie dimensies. Beeldstabilisatie vindt ook plaats in drie dimensies zodat voor een volledige analyse van de vestibulo-oculaire reflex oogbewegingen in drie dimensies gemeten dienen te worden. Daartoe maken veel researchgroepen gebruik van patiëntonvriendelijke oogmetingstechnicken 
(scleral-coil-technieken) die alleen kortdurend onderzoek mogelijk maken. Daarom werd in Maastricht, ten dele gebaseerd op eerder onderzoek van Clarke en Teiwes, een head mounted real time video-eyetracker ontwilkeld voor her pariëntvriendelijk kwantificeren van oogbewegingen in drie dimensies. In de loop van 1992 konden we dankzij Harry Gulikers en verscheidene medewerkers van de Instrumentele Dienst van de Universiteit, door een life demonstratie op de vergadering van de Nederlandse KNO-vereniging met trots een primeur presenteren: de eerste real time $3 \mathrm{D}$ binoculaire video-eyerracker ter wereld. Het concept werd vanaf 1997 verder geoptimaliseerd door Iwan de Jong en Jeroen Bosman, in nauwe samenwerking met de eerste gebruikers Boumans, Maas en Simonsz uit Rotterdam, en Wuyts, van de Heyningh en van Dijk uit Antwerpen. De ontwikkeling van een menselijke centrifuge en een hoge versnellingsslede door tal van medewerkers van de Instrumenrele Diensten van Universiteir en Ziekenhuis heeft er voor gezorgd dat we in de kliniek nu ook de funcrie van de utriculus en sacculus kunnen meten.

Parallel aan de 3D video-eyetracker ontwikkelden onze onderzoekers Jeroen Bosman en Iwan de Jong in samenwerking met Marcell ten Tusscher van de capaciteitsgroep Oogheelkunde een 2D binoculaire video-eyetracker die vrij van het hoofd op ongeveer 2.5 meter afstand de absolute oogstand van beide ogen kan meten. Het systeem is speciaal ontwikkeld om bij baby's vanaf de geboorte de ontwikkeling van de oculomotoriek, binoculariteit en vestibulooculaire reflexen te bestuderen.

Naast ruimtelijke oriëntatie en beeldstabilisatie zorgt het evenwichtsstelsel ook voor regeling van het houdingsevenwicht. De mens staat of zit over her algemeen rechtop, waardoor de handen vrij zijn om complexe taken uir te voeren. De evenwichtsorganen detecteren daartoe de stand van ons hoofd ten opzichte van de zwaarte- 
kracht en zorgen voor het zodanig aanspannen van spiergroepen dat het lichaam en vooral de ledematen voldoende stijfheid krijgen. Het evenwichtsstelsel regelt ook de oriëntatie van ons massazwaartepunt ten opzichte van het steunvlak, de voeten als we staan en het zirvlak als we zitten. Hiertoe maakt het gebruik van de interne representatie van ons lichaamsschema en berekent hoe de lichaamsstand moet zijn om niet om te vallen. Zolang ons massa-zwaartepunt zich boven het steunvlak bevindt vallen we niet om, anders vallen we, tenzij we het steunvlak en dus een voet verplaatsen. Bij een acute uitval van een evenwichtsorgaan valt deze spiertonus weg, weten we niet goed meer waar de zwaartekracht vandaan komt en vallen dus om. Bij de kat wordt niet de positie van het zwaartepunt geregeld, hier controleren de hersenen de stand van de poten; de poten worden zo snel mogelijk verticaal naar onderen gericht om op vier poten terecht te komen na een sprong of val.

De kwaliteit van het houdingsevenwicht wordt sterk gedomineerd door leerprocessen en motorische vaardigheden. Daardoor kan de houdingscontrole van een gezond mens met een zittend beroep bijvoorbeeld slechter zijn dan van een geoefend ballerina of acrobaat met een stabiel, centraal gecompenseerd, functieverlies van het evenwichtsorgaan.

Boven de 70 jaar vallen mensen gemiddeld 1-2 maal per jaar, met risico op ernstig invaliderend letsel. Het klinisch onderzoek naar de oorzaken van dit wallen alsmede van houdingsevenwicht in het algemeen is moeilijk. Het internationaal alom gerespecteerde onderzoek. van Bles met de kantelkamer heeft meer inzicht gegeven in houdingscontrole. Norré in Leuven toonde aan dat met stabilometrie het proces van centrale compensatie na acuut vestibulair functieverlies goed te kwantificeren is. Nashner en Allum bevestigden deze bevindingen met dynamische posturografie. Beide technieken, zowel stabilometrie als dynamische posturografie, hoe elegant en origineel ook, geven echter voor de kliniek onvoldoende informatie over 
de herkomst van chronische evenwichtsstoornissen. Het promotieonderzoek van Ayman El Kahky in Maastricht was erop gericht de gevoeligheid van vooral de dynamische posturografie te verhogen door te meten onder kritische omstandigheden waaronder patiênten nog juist het evenwicht konden bewaren. De bevindingen waren teleurstellend: de testen waren weliswaar gevoeliger en reproduceerbaarder dan bij de traditionele methodieken, maar konden nog steeds onvoldoeride discrimineren tussen patiênten met een verminderde functie van het evenwichtsorgaan en gezonden. Dynamische posturografie lijkt veel meer motorische vaardigheden dan de functie van de evenwichtsorganen te meten. Ons onderzoek naar houdingscontrole richt zich nu primair op het achterhalen van de invloed van de diverse zintuigen op her kunnen detecteren wat de lichaams-oriëntatie is, ren opzichte van de zwaartekracht ten behoeve van de houdingscontrole: onderzoek naar de subjectieve proprioceptieve horizontaal, waarbij het accent veel minder op motorische vardigheden ligt.

Samen met Philippe Perrin uit Nancy wordt mer behulp wan dynamische posturografie onderzoek verricht naar houdingsregulatie en bewegingsstrategieën bij sporters en ouderen. Onderzoek toonde onder meer aan dat Yoga en Tao Tchi waarschijnlijk een effectieve training van evenwicht en propriocepsis is en de valkans bij ouderen net zo zeer verlaagt als intensief sporten.

Stabilisatie van het hoofd in de ruimte is een onderdeel wan de totale lichaamsstabilisatie bij staan en lopen. De hoofdstabilisatie vindr plaats door de vestibulo-collic reflex die daartoe samenwerkt met dé cervico-collic reflex. Tijdens het lopen maakt her hoofd daardoor een vrijwel constante hoek met het sagitale vlak. Het vestibulair systeem lijkt op een top-down manier te werken, waarbij de hersenen wooral de stand van het hoofd in de ruimte sturen en veel minder de stand van het hoofd ten opzichte van de romp. Hierdoor kan de mens zich goed visueel blijven oriënteren. Bij patiënten die 
geen vestibulaire functie meer hebben, of bij kinderen die net leren lopen, wordt meestal een botum-up strategie gebruikt: het hoofd wordt stijf op de romp gehouden door verhoging van de tonus van de nekspieren. Dit leidt over het algemeen tot een minder optimale beeldstabilisatie. Bij duiven zou de beeldstabilisatie vanwege de lateraal geplaatste ogen gedisconjugeerd moeten verlopen. Bij een voorwaartse loopbeweging zou het rechteroog naar rechtsachteren en het linkeroog naar linksachteren moeten bewegen. De duif lost dit probleem op door in plaats van de ogen het hoofd in de ruimte te stabiliseren. Zo ontstaat de zogenaamde kop-nystagmus waarbil de stabilisatie van het hoofd in de ruimte plaatsvindt tijdens de langzame fase en het hoofd weer snel naar voren geplaatst wordr om alansluitend weer een compensatoire hoofdbeweging te kunnen maken. Deze kopbewegingen bij vogels illustreren hoezeer de evenwichtsfunctie om ons heen in het dagelijks leven geïntegreerd is maar vaak onopgemerkt blijft.

Voor een optimale blikstabilisatie moeten de vestibulo-collic reflex en vestibulo-oculaire reflex optimaal op elkaar afgestemd zijn. Als we vanuit een stoel opstaan om te gaan lopen willen we bij voorkeur onze blik meenemen om ons op de visuele omgeving voor ons te oriënteren. Daartoe onderdrukken we bij het opstaan de vestibulo-oculaire reflex. Uit recente nog ongepubliceerde resultaten wan een Amerikaanse onderzoeksgroep is gebleken dat deze onderdrukking bij ouderen met een hoge valkans verminderd is: ze zijn vlak na het opstaan niet meer in staat zich visueel ruimtelijk te oriënteren ondar de blik door de vestibulo-oculaire reflex op de grond vlak voor hen gericht blijft. Bestudering van deze typische evenwichtsstrategieèn helpt ons derhallve om problemen als het vallen bij ouderen structureel aan te pakken, vooral door aangepaste revalidatie.

De mens oriënteert zich in de ruimte ook grotendeels in hoofdcoördinaten, waarschijnlijk omdat evenwichtsorganen en ogen, on- 
ze belangrijkste zintuigen voor oriëntatie, zich in het hoofd zelf bevinden. Als we bewust een andere richting uit gaan lopen, richten we meestal eerst het hoofd en de blik in de richting van ons doel, stabiliseren deze hoofd- en oogoriëntatie, en bewegen ons vervolgens in de ingeslagen weg. We lopen ons hoofd achterna.

Ook tijdens het hardlopen moeten we ons hoofd in de ruimte goed stabiliseren yoor een optimale ruimtelijke orièntatie. Tijdens lichaamsbewegingen wordt het hoofd in de ruimte gestabiliseerd middels de vestibulo-collic reflex. Patrick Huygen uit Nijmegen toonde aan dat als beide evenwichtsorganen niet meer functioneren de propriocepsis in de nek de rol van het evenwichtsorgaan bij de hoofdbewegingen beperkt kan overnemen. Daarmee werd duidelijk hoe belangrijk de multi-sensorische input en het aanpassingsvermogen van het evenwichtsstelsel zijn en dat er een relatie bestaat tussen funcrie van nekspieren en oogbewegingen, iets waarvan het anaromisch substraat al uitgebreid beschreven is door onder meer Victor Wilson. Dit laatste aspect benadrukt ook de relatie tussen nekfunctie, hoofdstabilisatie, beeldstabilisatie en ruimtelijke oriërntatie. Bij whiplash treedt vaak nekletsel op hetgeen hoofd en beeldstabilisatie negatief kan beïnloeden. Mogelijk is dit laatste een substraat voor de door whiplash patiënten gemelde overgevoeligheid voor drukte en stress, voor sneller optredende vermoeidheid en cognitieve stoornissen. Immers een goede hoofd- en beeldstabilisatie zijn voorwarden voor een goed dynamisch ruimtelijk oriëntatievermogen en veel cognitieve taken vinden plaats onder dynamische omstandigheden. Marike van der Horst hoopt met haar onderzoek bij kop-staartbotsingen onder leiding van Jacques Wismans van TNO-Delf, Dick van Campen van de TUE, Henk van Mameren (capaciteitsgroep Anatomie, UM), Jaap Patijn (Pijnteam azM) en ons, een beter inzicht te krijgen in de rol van de nekspieren bij het letselmechanisme van de nek. Centraal bij dit onderzoek staat de optimalisatie van een biomechanisch model van het hoofd-nek 
systeem om de passieve en actieve veiligheid van het autorijden te verbeteren.

Ik heb $U$ in het voorgaande een overzicht gescherst van het middels wetenschappelijk onderzoek zoeken naar oplossingen om de functie van onze evenwichtsorganen beter te kunnen meten in relatie tot ruimtelijke oriêntatie; beeldstabilisatie en houdingsevenwicht. $\mathrm{Na}$ ruurlijk heeft de binnen onze afdeling verworven kennis en ervaring een eigen geschiedenis die ik $U$ nier will onthouden.

De Evenwichtsafdeling in Maastricht is uit het niets ontstaan: ze werd in de loop van 1982 op instigatie van Ed Marres door Paul Stegeman, nu KNO-arts in Veghel, opgezet. In dit eerste uur waren ook Jacques Hendriks, Lucien Anteunis en John Huntjens stuwende krachten. Eind 1983, komend uir het uitzonderlijk goed uitgeruste Leidse Biofysica laboratorium van mijn promotor Professor Lou Duysens in Leiden, constateerde ik tor mijn schrik dat er geen echre meetsystemen beschikbaar waren om kwantitatieve onderzoekingen te kunnen uitwoeren. Wel had de staf $\mathrm{KNO}$ dankzij steun van Professor Bonke en gefinancierd door het toenmalige St. Annadal zjekenhuis en de UM, de toentertijd meest geavanceerde draaistoel voor onderzoek weten te bemachtigen. In de jaren daarop ontwikkelden onze computerteclanicus John Huntjens en ik daarom een flexibele data-acquisitie en stimulatie omgeving. Hiermee konden we allerlei visuele en vestibulaire stimuli genereren en responsies opslaan, analyseren en kwantificeren. Parallel aan deze ontwilkkelingen in Maastricht, blies Marres nieuw leven in een bij velen in Nederland gekoesterde wens om tor de oprichring van een landelijke vestibulaire werkgroep te komen. Binnen deze werkgroep werd her initiatief genomen om in Maastricht een nascholingscursus voor $\mathrm{KNO}$-artsen en neurologen te organiseren, inmiddels op initiatief van Leon Boumans atangevuld met een nascholingscursus in Rotterdam voor ENG laboranten of "vestibulair assistenten". De 
werkgroep en cursus zorgden voor veel discussie tussen $\mathrm{KNO}$ artsen, neurologen, biologen en fysici. Consensus inzake diagnostiek en behandeling van evenwichtsstoornissen leek ver weg. Het initiatief tot instelling van een standaardisatiecommissie werd genomen, waaran Boumans, Fischer, Norré, Oosterveld en van Vliet een groce bijdrage leverden. Een aantal richtijnen werden opgesteld vanwaar uit verdere ontwilkkeling mogelijk was. Samen met de industrie werden de richtlijnen inzake standaardisatie van apparatuur en methodieken geimplementeerd zodat uirwisselbaarheid van gegevens werd gerealiseerd. Het computersysteem werd in nauwe samenwerking met de industrie, de firma Jaeger-Toennies, onze collegae uit Rotterdam, Boumans en Maas, door Iwan de Jong tot een volledig gestandaardiseerd, computergestuurd meetinstrument voor evenwichtsonderzoek ontwikkeld, dat aansluitend door Jaeger-Toennies gecommercialiseerd werd. Marlies Dolmans, zorgde als ENGlaborante samen met diverse gebruikers in den lande voor de noodzakelijke feedback en kritiek vanuit de praktijk. Inmiddels zijn de gestelde normen door veel fabrikanten wereldwijd overgenomen. Het eigen computersysteem werd in de daarop volgende jaren steeds verder uitgebreid ten behoeve van ons wetenschappelijk onderzoek.

Ton Fischer nam het initiarief om op basis van de inbreng van vele deskundigen bij de nascholingscursus het eerste Nederlandstalige leerboek op her gebied wan duizeligheid en evenwichtsstoornissen tot stand te brengen. Dit leidde tot een klinisch zeer bruikbaar naslagwerk voor $\mathrm{KNO}$-arts, neuroloog en huisarts en werd door vele Nederlandse geneeskunde studenten als leerboek geraadpleégd.

Met het bovenstaiande heb ik willen aangeven dar de ontwikkeling van het evenwichtsonderzoek in Nederland gevoed wordt door velen en dat zij oole de opbouw in Maastricht daarmee mede mogelijk hebben gemaakt, iets waarvoor ik hen allen oprecht dankbaar ben. 


\section{DE TOEKOMST}

Het wetenschappelijlk onderzoek inzake vestibulologie vindt plaats binnen het onderzoeksinstituut Hersenen en Gedrag, divisie Basale Neurowetenschappen wan de Universiteit Maastricht. Het instituut kent een sterk multidisciplinair karakter waardoor samenwerking met andere, voor ons belangrijke klinische capacireitsgroepen zoals bijwoorbeeld Neurologie en Oogheelkunde, maar ook met basiswerenschappers vanuit de divisie Basale Neurowetenschappen zoals neurobiologen en neuropsychologen zonder meer gefaciliteerd wordt. Ik wil de samenwerking binnen de divisie Basale Neuro- wetenschappen ook verder invulling geven door het initiëren van dierexperimenteel onderzoek naar het effect van pharmaca op het voorkomen van bewegingsziekte en het optimaliseren van neuroplasticiteit na vestibulair functieverlies.

Samenwerking mer de andere klinisch fysici in het ziekenhuis is vanzelfsprekend, omdat we elkaar vaak valkinhoudelijk kunnen bijstaan, ondanks de soms wel heel verschillende werkterreinen zoals vestibulologie, audiologie, neurofysiologie, radiotherapie, beeldvormende diagnostiek, nucleaire geneeskunde enz. Voor (klinisch en bio)fysici werkzaam in het azM is de inmiddels structurele samenwerking tussen TUE en UM via de faculteit Biomedische Technologie een grote stimulans en biedt tal van kansen. Ik ben ervan overtuigd dat ook de afdeling Biomedische Technologie i.o. binnen het axM aansluiting bij deze ontwikkelingen zal vinden waarbij de klinisch fysici een belangrijke en stimulerende rol kunnen spelen en de opleiding tor Klinisch Fysicus verder structuur kan krijgen. Zintuigfysica is een vakgebied dat mij met onze fysici-audiologen en Jos Reulen, fysicus bij de Klinische Neurofysiologie, bindt: samen kunnen we juist ook dat vak binnen de BMT doceren en de aandacht geven die het verdient. 
Ons evenwichtslaboratorium bevindt zich in het ziekenhuis binnen de polikliniek $\mathrm{KNO}$, en is ook organisatorisch ondergebracht bij de afdeling KNO. Samen met collega Robert Srokroos, KNO-arts, ben $i \mathrm{k}$ werantwoordelijk voor de zorg voor de duizelige of evenwichtsgestoorde patient. Bij de complexe evenwichtsdiagnostiek is het samenspel tussen medicus en fysicus essentieel rond de thema's waar ze en verschillende deskundigheid in hebben: anamnese, technisch evenwichtsonderzoek, aanvullende medische diagnostiek en behandeling: Alle medische afdelingen kunnen rechtstreeks naar onze afdeling verwijzen zodat de inbedding bij KNO slechts voordelen en geen nadelen kent. Hierdoor bestaat er ook een witstekende samenwerking met de afdelingen Neurologie en Oogheelkunde, zonder hinderpallen. Het staat mij voor ogen deze samenwerking verder uit te bouwen in de vorm van een Dizziness unit om zo te komen tot een nog efficiëntere structurele multidisciplinaire benadering van patiênten met complexe evenwichts- of oculomotor problematiek. Ontwikkeling wan behandelingsprotocollen en evaluatie van de behandeling van evenwichtsstoornissen en duizeligheid is een aspect van de patiëntenzorg en het wetenschappelijk onderzoek dat met de komst van Robert Stokroos duidelijk aandache heeft gekregen en verder uitgebouwd zal worden. Samen houden we een regulier evenwichtsspreekuur waar patiënten met complexe vestibulaire problematiek worden onderzocht, behandeld en begeleid.

Dankzij het initiatief van Hans Vles en onder meer collega's van. Chirurgie, Fysiotherapie, Klinische Neurofysiologie, Orthopedie, Revalidatie in het azM, het IRV en Fransiscusoord, de capaciteirsgroep bewegingswetenschappen en met steun van de Raad van Bestuur van het azM, wordt nu een lklinisch bewegingslaboratorium in het az $M$ ingericht. Daar zal, naast onderzoek naar het effect van botuline behandeling op spasticiteit, onderzoek naar motoriek en houding in her algemeen, ook de specifieke rol van her evenwichtsstelsel op houdingscontrole tijdens beweging bestudeerd worden. 
Her aan dit bewegingslaboratorium gekoppeld Houdings- en Bewegingsstoomissentean maakt het mogelijk de kennis te bundelen vanuit alle relevante disciplines. Ik hoop daamee ook meer voortgang met de diagnostiek wan evenwichtsstoornissen te boeken. Het wetenschappelijk onderzoek ter zake is ondergebracht bij de divisie Basale Wetenschappen. Samenwerking inzake de klinische en wetenschappelijke activiteiten van het bewegingslaboratorium op eurregionaal niveau ligt met de instelling van de Transnationale Universiteit Limburg binnen het bereik.

Is de ontdekkingsreis van het zesde zintuig ten einde? Nee, in tegendeel, ik hel het gevoel dat we slechts aan het begin zijn van de lange, moeizame tocht naar de top, maar we hebben wel een goed pad naar boven gevonden. 
Mijnheer de rector Magnificus, Dames en Heren, woor deze benoeming en voor het in mij gestelde vertrouwen, dank ik $U$ en het College van Bestuur van de Universiteit van Maastricht, het Bestuur van de Faculteit der Geneeskunde, de Raad van Bestuur van het academisch ziekenhuis Maastricht en het bestuur van de stichting Annadal en alle anderen die aan de torstandkoming van deze leerstoel hebben bijgedragen.

Hooggeleerde Marres, beste Ed. Jij had de visie dat Maastricht zich vooral op het gebied van het evenwichtsonderzoek nationaal en international zou kunnen profileren. Toen ik in 1983 als biofysicus voor deze taak door jon werd aangenomen, bleek de vacature plotseling geblokkkeerd. Maandenlang, terwijl ik mijn proefschrift afrondde, belde je mij iedere week op om mij en waarschiinnlijk ook jezelf moed in te spreken. Toen de dwarsliggende bestururders op vakantie waren, greep je je kans en was mijn aanstelling binnen 24 uur rond. Samen met de gehele afdeling KNO heb je mij altijd gesteund en gestimuleerd om de afdeling op te bouwen tot dat wat zij nu geworden is. Ik genoot een wolledige vrijheid van handelen, kreeg alle kansen die een mens zich maar kan wensen. Met Katrien zorgde jij alrijd voor een klimaat van fijn werken, gastvrijheid en vriendschap. Mijn dank is heel groot.

Hooggeleerde Manni, beste Hans, als iemand mijn eventueel hoogleraarschap weer ter sprake had gebracht in de afgelopen jaren, zuchtte je vaak diep en vertelde me dat er nog geen zicht was op een benoeming. Ongeveer twree jaar geleden kwam je samen met Nels bij ons thuis, ontkurkte je met een glimlach de fles omdat de procedure eindelijk echt in gang gezer kon worden. Zaken die aangeven dat het allemal niet zo eenvoudig ligt en dat je ook weer niet zo maar hoogleraar wordt, ook al zeggen ze bij de Universitaire Toga winkel dat er 
best well heel veel professoren zijn. Uiteindelijk is het toch voor elkaar gekomen en daar ben ik je bijzonder dankbaar voor.

Hooggeleerde Troost, beste Jaap, je bent een man van weinig woorden, maar een groot leider met grote daden, integer, recht door zee, deskundig en rechtvaardig. Je hebt mij steeds gesteund en mijn benoeming met daadkracht mogelijk gemaakt. Het is een eer en genoegen je te kennen. Ik leer van van iedere ontmoeting. Ik ben je bijzonder dankbaar.

Hooggeleerde Vles, beste Hans, je bent een echte vriend, een heel goede vriend, een dierbare wriend, een eerlijke vriend, een gekke vriend, een soms heel erg moeilijke vriend, een indrukwekkend deskundige kinderneuroloog met wie ik het een eer en genoegen vindt om nauw mee samen te werken.

Zeergeleerde Parijn, beste Jaap. Al vele jaren onderzoeken we samen de relatie tussen duizeligheid, evenwichtsfunctie en stoornissen van het bewegingsapparaat en zijn we de beste vrienden geworden. Je bent een echte dokter met leesbril, je hebt een warm hart, een groot gevoel voor humor en credit cards die het altijd overal ter wereld doen om je vrienden even te helpen als het moet. Ik ben blij dat ik jou en Inge heb leren kennen. Dank je wel voor alles.

Zeergeleerde van der Beek, beste Johan. Jij hebt mij bij het opzetten en ontwikkelen van de evenwichtsafdeling altijd en jarenlang gesteund. Je was een wriend die waar ook en wanneer ook hulp bood, bij het werk en privé. Ik dank jou en Elly heel erg voor de vriendschap.

Hooggeleerde Jolles, beste Jellemer, jij hebt het onderzoek van mij een plaats gegund binnen her onderzoeksinstituut Hersenen en Gedrag. Daarmee was de bescheiden onderzoeksformatie vin KNO eindelijk echt formeel maar ook zinvol gelabeld en was de weg geopend naar verdere facultaire erkenning. Ik ben je zeer dankbaar voor het in mij gestelde vertrouwen en je steun op cruciale momenten. 
Hooggeleerde Steinbusch, beste Harry, na de reorganisaties is her zintuigfysiologisch onderzoek van $\mathrm{KNO}$ volledig binnen "onze" divisie Basale Neurowetenschappen ondergebracht en kon de facultaite labeling gecontinueerd worden. Ik dank jou voor je steun en vertrouwen. Ik hoop in de komende jaren onze samenwerking ook in de vorm van samenwerkingsprojecten meer inhoud te geven.

Hooggeleerde Wismans, beste Jacques, onze contacten zijn vooral beperkt tot klankbordvergaderingen rond het promotie onderzoek rond het thema "biomechanica van nekletsel bij autobotsingen" in het kader van de samenwerking tussen de TUE en de UM. Jij bent de initiator van deze samenwerking geweest en inmiddels heeft dat direct en indirect vruchren afgeworpen. Hartelijk dank woor je steun.

Weledelzeergeleerde Adam, beste Jos, ik wil je graag bedanken voor de goede samenwerking bij jouw onderzoek op het gebied van oog-hand coördinatie; een schoolvoorbeeld van een situatie waarin wetenschappers elkaar vooruit kunnen helpen, gewoon op basis van onderling vertrouwen en waardering.

Weledelzeergeleerde Ten Tusscher, beste Marcel, jij was de neuro-ophthalmoloog in het azM die met grote deskundigheid oogbewegingsstoornissen wist te interpreteren. Je was een onmisbare schake in ons multidisciplinair team en ontwikkelde je als het brein achter het onderzoek van jouw promovendus Jeroen Bosman. I dank je heel bijzonder voor je hulp en vriendschap.

Hooggeleerde Oosterveld, beste Wil, jij en jouw medewerkers hebben miy de eerste grondbeginselen van het evenwichtsonderzoek bujgebracht. Je hebt mij met veel zaken geholpen en gesteund, waarvoor ik je bijzonder dankbaar ben.

Hooggeleerde Bonke, $U$ heeft een belangrijke rol gespeeld bij de profilering van Maaastricht op her gebied van de westibulologie. Eerst heeft $U$ er mede voor gezorgd dat er formatie en apparatuur kwam voor het opzetren van de evenwichtsafdeling en vervolgens 
heeft $\mathrm{U}$ als toenmalig decaan van de Faculteit der Geneeskunde ervoor gezorgd dat het licht echt op groen ging voor de benoemingsprocedure: Ik ben U bijzonder dankbaar.

Weledelzeergeleerde Carpay, weledelgeleerde Brans Brabant. Zonder $U$ was er geen evenwichtsafdeling en kwam er geen bewegingsllaboratorium in, zoals mijn buitenlandse gasten altijd zeggen, her mooiste en indrukwekkendste ziekenhuis dat ze ooit gezien hebben. Ik dank $U$ zeer.

Beste stafleden $K N O$, zonder het committent van jullie dat evenwicht het topprofiel van de KNO-Maastricht mocht zijn, was het nooit gelukt. Ik ben iedereen daarvoor bijzonder dankbaar. I $\mathrm{k} \mathrm{dank}$ niet alleen de gehele staf, maar tevens alle overige medewerkers van KNO voor hun positieve instelling en hulp; dat heef mij enorm geholpen de evenwichtsardeling tot iets dynamisch te laten uitgroeien.

Heel erg in het bijzonder ben ik de medewerkers van de evenwichtsafdeling en "mijn" secretaresses dankbaar voor de hulp, steun en creativiteit en vooral jullie geduld met mij: bedankr John Huntjens, Lucien Anteunis, Paul Sregeman, Marlies Dolmans, Iwan de Jong, Erik Brandts, Marèse Gordijn, Anouk Brands, Ron Jongen, Ellen Ackermans, Sophie Paredis, Nadia Hendrices, Pauline Kruiniger, Joyce Prins en Hella Wilmes.

Studenten Geneeskunde, Bewegingswetenschappen, Natuurkunde, Technische Computerkunde, ik dank jullie allen voor de bijdragen die jullie leverden aan ons onderzoek in de vorm van tallowe wetenschaps-en afstudeerprojecten. Ik dank jullie ook voor het feit dat ik jullie college mag geven, want dat doe ik graag.

"Mijn" 7 promovendi tot nu toe dank ik voor het feit dat ik hun copromotor mocht zijn en dat ze met hun werk en inzet bijgedragen hebben tot wat nu tot stand gekomen is.

Ilk dank alle medewerkers van de Instrumentele Dienst van Faculteit en Ziekenhuis, de Audiovisuele Dienst: zonder jullie was er niets. 
Ik wil met nadruk alle leden van de Nederlandse Vestibulaire Vereniging danken woor het feit dat zij de ontwikkeling van ons vakgebied in Nederland nieuwe impulsen hebben gegeven. Daarmee is ook de gescherste ontwikkeling in Maastrichr mogelijk gemaakt en ik vraag hen mij in de komende jaren bij te staan mijn benoeming een zo goed mogelijke invulling te kunnen gever.

Ik ben mijn ouders heel erg dankbaar voor het feit dat ze mij altijd zo gestimuleerd hebben vooral te leren en te studeren. Ze gaven me ook een brede achtergrond mee, waarin naast het voor noorderlingen bekende plichtsbesef, de nuchterheid, de passie voor het discussierren, ook de liefde voor de muziek en kunst een warme plaats in mijn hart kreeg. Soms hielden jullie je hart vast omdat mijn ontdekkingsreis wel eens wat al te onconventioneel leek en riep mama: och jongen toch, kijk je wel een beetje uit? Maar zo zie je maar: het is allemaal toch nog goed gekomen. Ook mijn broers en zussen die hun bezige broertje maar zo weinig zien en horen: jullie zijn hele lieve en bijzondere mensen.

Ik dank de Vava voor zijn voortdurende steun en betrokkenheid.

Lieve Hilde, Boris, Sanne en Bouke, jullie zijn het liefste en dierbaarste wat ik heb.

rk beb gezegd 


\section{AANBEVOLEN LITERATUUR}

Baloh RW, Halmagyi GM. Disorders of the Vestibular system. Oxford Universicy Press New York, 1996. ISBN 0-19-509006-3

Brandt T. Vertigo. Its Mulrisensory Syndromes. 2nd Edition. Springer Verlag London, 1999. ISBN 3-540-19934-9

Curthoys IS, Halmagyi GM. Vestibular compensation: a rewiew of the oculomotor, neural and chinical consequences of unilateral westibular loss. I Vext Res 1995:5:67-107.

Wilson VI and Melvill Jones G. Mammalian Vestibular Physiology. New York, Plenum Press, 1979 